DOI: $10.14746 /$ por.2018.2.18

\title{
ARTYSTA I MIT. WOKÓŁ TREŚCI UCZUCIOWEJ REWOLUCJI ANDRZEJA WRÓBLEWSKIEGO
}

\author{
DARIA NOWICKA ${ }^{1}$ \\ (Uniwersytet im. Adama Mickiewicza w Poznaniu)
}

\begin{abstract}
Słowa kluczowe: Andrzej Wróblewski, Tadeusz Różewicz, sztuka powojenna, pamięć, poezja, modernizm, mit, archetyp, sygnatura Keywords: Andrzej Wróblewski, Tadeusz Różewicz post-war art, memory, poetry, modernism, myth, archetype, signature
\end{abstract}

\begin{abstract}
Abstrakt: Daria Nowicka, ARTYSTA, MIT I METAFORA. WOKÓŁ TREŚCI UCZUCIOWEJ REWOLUCJI ANDRZEJA WRÓBLEWSKIEGO. „PORÓWNANIA” 2 (23), 2018. T. XXIII, S. 259-278. ISSN 1733-165X. Niniejszy artykuł koncentruje się na obecności wyobraźni mitologicznej w twórczości jednego z najwybitniejszych malarzy powojennych. Autorka podejmuje w nim próbę zdefiniowania mitu obecnego w dziełach Andrzeja Wróblewskiego powstałych w latach czterdziestych i pięćdziesiątych. Zwraca uwagę na trzy możliwe sposoby jego odczytania. Stąd omówieniom poddaje mit orficki, mit odrzuconego artysty oraz mit nowego kosmosu. Interpretacja sztuki Andrzeja Wróblewskiego skierowana jest dodatkowo na omówienie kilku problemów, między innymi: statusu jego obrazów we współczesnej krytyce, rewersów biografii artystycznej, a także języków modernizmu, jakie od lat pięćdziesiątych funkcjonują w opowieściach o malarzu.
\end{abstract}

Abstract: Daria Nowicka, ARTIST, MYTH AND METAPHOR. ABOUT “TREŚĆ UCZUCIOWA REWOLUCJI" BY ANDRZEJ WRÓBLEWSKI. "PORÓWNANIA" 2 (23), 2018. Vol. XXIII, P. 259-278. ISSN 1733-165X. This article focuses on the presence of mythological imagination in the work of one of the greatest post-war painters. The author defines the myth present in the works of Andrzej Wróblewski created in the 1940s and 1950s. The author presents three possible ways of understanding the myth: the myth of Orpheus, the myth of a lonely artist and the myth of a new cosmos. The author also discusses other problems: the status of his paintings in contemporary criticism, the reverse of artistic biography and languages of modernism from the 1950s.

1 E-mail: daria.nowicka@amu.edu.pl 
Ale sam mit jeszcze pozostaje „niemy”, jak go ujmują bliskie nam interpretacje [...] (Juszczak 55)

We wrześniu 2018 roku w Muzeum Śląskim w Katowicach zakończyła się jedna z istotnych wystaw memorialnych ostatnich lat - Perspektywa wieku dojrzewania. Szapocznikow - Wróblewski - Wajda. Jej kuratorką była Anda Rottenberg, historyczka sztuki, eseistka, badaczka pogranicza sztuk wizualnych i literackich, autorka wstępu do albumu powystawowego zatytułowanego Świadectwa czasu dojrzewania. Ujęcie konstelacyjne wpisane już w sam tytuł wystawy (a mowa tu zwłaszcza o podobieństwie tożsamościowym artystów tworzących w cieniu roku 1949 i po nim, należących do pokolenia „zarażonych wojną") jakie zaproponowała Rottenberg, przyczynia się obecnie do nowych odczytań twórczości tych trzech artystów.

Wspomnienie tej wystawy i jej głównych założeń, którymi było: utrwalenie pamięci osobistego doświadczenia, ukazywanie dialogu języka sztuki, języka literatury, języka filmu, rewizjonowanie sztuki powojennej, zdaje się nie tylko pozostawać zharmonizowane z dotychczasowymi badaniami nad twórczością autora Nieba nad górami, ale w pewnym stopniu również je rozszerza i modernizuje. Świadczy też o postępującym procesie (de)mitologizacji Wróblewskiego jako artysty-malarza, Wróblewskiego jako człowieka uwikłanego w narracje.

Mit sztuki Wróblewskiego rozpatrywano początkowo w dwóch pierwotnych znaczeniach. Po pierwsze, wiązano go z portretem samego artysty, jednostką osamotnioną, zmagającą się z przeciwnościami historii - Wróblewski jako świadek i obserwator II wojny światowej, malarz (soc)realizmu, poddany, ale i poddający się przeciwnościom losu. Po drugie, mit rozumiany jako proces, realizacja procesu pozwalał na osadzenie sztuki artysty w kontekście malarstwa i literatury europejskiej.

Pierwsze próby odczytania twórczości Wróblewskiego w oparciu o mit przypadły na lata osiemdziesiąte. Wówczas to, w 1987 roku, w Muzeum Archidiecezji Warszawskiej zorganizowano wystawę gwaszy artysty, łącząc je z malarstwem i grafikami Antona van Dycka i Petera Paula Rubensa. Prezentację opatrzono tytułem „Ekspresja i mit. Gwasze Andrzeja Wróblewskiego - Malarstwo i grafika Rubensa i van Dycka". Owo umieszczenie twórczości autora Rozstrzelań na osi europejskiej historii sztuki w znacznej mierze spowodowało zainteresowanie jego twórczością. Mimo iż akcent położono wówczas przede wszystkim na analizę form ekspresji i jej genealogii oraz ustalanie tożsamości artystów modernizmu wystawa zainaugurowała ważną, choć lapidarną dyskusję nad zakresem i znaczeniem mitu jako pojęcia i kategorii badawczej w twórczości Wróblewskiego. 
Warto wspomnieć, że był to również początek coraz bardziej otwartego wiązania twórczości artystycznej Wróblewskiego z recepcją literacką. Można to zauważyć zwłaszcza w recenzjach z wystawy, w których Wróblewskiego nazywano malarzem Aragona, a nawet malarzem myśli gombrowiczowskiej. Lata dziewięćdziesiąte obfitowały pod tym względem jeszcze bardziej. Od samego początku artysta figurował więc jako malarz skrajnych recepcji literackich. Jego idiom malarski, tak znacząco odmienny od ówczesnej działalności artystycznej pozostałych rówieśników, przekładał się na osobność poetów tworzących w czasie Zagłady i w okresie powojennym.

Te dwa początkowe znaczenia mitu - opowieść o artyście i świecie oraz konstrukcja artystyczna - zdają się być zauważane również przez Rottenberg, która we wstępie do wspomnianego wcześniej katalogu z wystawy pisała o sile oddziaływania obrazów na zbiorową wyobraźnię:

[...] utwory artystyczne są fikcją, nie mogą zatem stanowić rzeczywistego świadectwa. Nie są więc nim również pozostawione nam dzieła trojga artystów. Rozpatrywane na płaszczyźnie sztuki są jednak czymś znacznie silniejszym i ważniejszym, zawarte w nich wizje lokują się bowiem w zbiorowej wyobraźni i zasilają ikonosferę pamięci. Społeczeństwa, które są tej pamięci pozbawione, nie mają też świadomości, że mogą się łatwo skazać na powtórzenie wszystkich, już raz doświadczonych tragedii (Rottenberg 186).

Analizy Rottenberg prowokują w pewnym stopniu do zastanowienia się nad mitem jako wędrującym pojęciem, pojmowanym zgodnie z założeniami Mieke Bal. $Z$ jednej strony chodziłoby o konieczność zachowania i rozwoju nurtu interdyscyplinarnych badań sztuki Wróblewskiego (z uwzględnieniem uniwersalności problemów artystycznych), z drugiej natomiast mit tak rozumiany pozwalałby na zachowanie, zdaje się koniecznego, pierwiastka indywidualizmu $\mathrm{w}$ interpretacjach jego sztuki. Twórczość autora Nieba nad górami w znacznej mierze zbudowana została bowiem na dychotomiach i sprzecznościach, których artysta doświadczył osobiście:

Kim jest Andrzej Wróblewski? Ma dwadzieścia jeden lat, maluje inne, nieprzewyższone obrazy. Ale jaki jest jego umysł? Repatriacja, przybysz, miejsca wielkiego smutku i choroby, miejsca puste, skryte, zmienione, miejsca przyśpieszonego rozwoju, widzenie i ciekawość świata (Michalski 1993: 13).

Stąd istotne zdaje się potraktowanie mitu w znaczeniu szerokim jako konstruktu kulturowego, potrzeba odczytywania dzieł artysty w kontekście biograficznym i w odniesieniu do społeczności - w interesującym mnie tu przypadku: w kontekście literackim, a zwłaszcza zaś poezji powstającej po 1948 roku. Zarówno postać artysty, jak i poruszana przez niego w malarstwie, rysunku i krytyce publicystycznej problematyka historyczno-społeczna zdają się odpowiadać w pewnym stopniu również Eliadowskiemu wiązaniu mitu z relacyjnością nie tyle w znaczeniu pier- 
wotnym, sakralnym, ale w sposobie odniesienia do tekstów kultury, jakimi posługiwał się artysta. To wszystko prowadzi również do koniecznego rozważenia granicy mitu i jego modernizacji.

W tym też przypadku istotna pozostaje periodyzacja, znaczenie przełomu lat 1948 i 1949 oraz próba zdefiniowania mitu w kontekście pokrewieństwa sztuki z literaturą. Interesować będzie mnie zatem rozumienie mitu, jakie jest proponowane we współczesnych badaniach kultury pamięci. W Modi memorandi. Leksykonie kultury pamięci pod redakcją Magdaleny Saryusz-Wolskiej oraz Roberta Traby można znaleźć następujące zapisy:

Mit [...] zachowuje zawsze bliskie związki z zagadnieniem pamięci. [...] Mitologia to nie zbiór opowieści, a raczej repertuar właściwych działań i modelowych sposobów refleksji. [...] (Napiórkowski 237).

Szczególnie rozwinięte są prowadzone [...] badania nad narodzinami nowoczesnej tożsamości narodowej, która okazuje się zawsze ufundowana na rodzaju opowieści mitycznej przekształcającej określony czas historyczny w źródłowy „czas początku”. Mimo że tego rodzaju praktyki opierają się na tekstach i ich interpretacji, to do społecznego obiegu trafiają za pośrednictwem zbiorowych praktyk upamiętniania (Napiórkowski 238).

I dalej w podrozdziale Pamięć w micie czytamy o pamięci jako przedmiocie opowieści mitycznej:

Szczególnie wyraźnie ten [pamięciowy - D.N.] aspekt mitów wydobywa ugruntowana w psychoanalizie teoria archetypów Carla Gustava Junga (1875-1961). Zarówno on sam, jak i jego następcy (Mircea Eliade [1907-1986], Joseph Campbell [1904-1987]), podkreślają związek pamięci w micie z ponownym scaleniem tego, co rozproszone (Napiórkowski 239).

Kilka postulatów obecnych w przywołanych fragmentach ma konkretne odwzorowanie w poetyce artystycznej Wróblewskiego. Mam głównie na myśli zaakcentowanie różnicy między „mitem" jako opowieścią, narracją (nie)dokończoną, a "mitologią" jako rezerwuarem, ponownie rekonstruowanym archiwum. W interpretacjach obrazów Wróblewskiego szczególną uwagę zwraca się bowiem na nieustanną aktualizację myśli malarza-artysty. Jego obrazy, zwłaszcza te dotyczące wojny, powojnia, wpisują się w romantyczną definicję fragmentu jako niekończącego się dzieła. Widać to chyba najlepiej w znanym cyklu autora, Rozstrzelaniach. To seria obrazów przedstawiających niebiesko-sine, wygięte, pokawałkowane i fragmentaryzowane postaci, ustawione pod ścianą, oczekujące na oddanie $\mathrm{w}$ ich kierunku śmiertelnych strzałów. Seryjność tych przedstawień, następstwo, ale też i posługiwanie się przez autora silną, wizualną metaforą, stają się przykładem artystycznego powtórzenia. 
Ponadto sztuka Wróblewskiego powstająca na przełomie lat czterdziestych i pięćdziesiątych $X X$ wieku korespondowała z mitem opowieści historycznej, mitem artysty odrzuconego przez naród. W tym kontekście warto wspomnieć o trudnościach związanych z próbą przypisania Wróblewskiego do jakiegokolwiek pokolenia czy grupy artystycznej. Jako twórca nie w pełni doceniony za życia, mający świadomość tego stanu, silnie akcentował swoją niezależność i osobność, przenosząc te tożsamościowe problemy na sztukę. Osobność ta nie wynikała wyłącznie z postawy, Wróblewski za życia mówił o sobie, że jest już po stronie "głosu umarłych", starał się utożsamiać z tym, co nieobecne.

I wreszcie twórczość autora Rozstrzelań jawi się również jako powracająca rzeczywistość mityczna, sztuka konstytuująca mitologiczne narracje. Związana jest ona z poszukiwaniem najnowszych reprezentacji literackich sztuki Wróblewskiego w twórczości polskich poetów, eseistów, pisarzy. Nie mam tu jednak na myśli wyłącznie poetyckich ekfraz czy posługiwania się przez poetów metaforami zaczerpniętymi z twórczości Wróblewskiego, ale znacznie istotniejszy problem - podobieństwo języków artystycznych i reagowanie poetów na niebezpieczeństwo zatracenia mitu, utraty pamięci. O obecności sztuki Wróblewskiego w poezji świadczą między innymi utwory: Juliana Kornhausera, Tadeusza Śliwiaka, Romana Honeta, Zbigniewa Herberta czy Tadeusza Różewicza. W niniejszym szkicu (w części czwartej), w celu przedstawienia relacji sztuki do mitu, odwołam się tylko do odczytań autora zawsze fragment. recycling.

\section{2}

Wróblewski, jeden z najwybitniejszych artystów powojennych, malarz osobny, współzałożyciel i ideolog Grupy Samokształceniowej, którą współtworzył między innymi z Andrzejem Wajdą, pozostawał w swojej sztuce rozdarty między malarstwem realistycznym a figuratywnym. Prace osadzone w rzeczywistości, możliwość przedstawiania $\mathrm{w}$ nich wydarzeń politycznych, ukazywanie poprzez nie dylematów tożsamościowych pozwalały na swoisty rodzaj zespolenia jego sztuki $\mathrm{z}$ tak zwanym i pozornie nowym życiem po wojnie. Obrazy realistyczne wyznaczały jednak granice re-prezentacji, nie tworzyły bowiem narracji ani nie dawały na nią szansy, a jedynie ją odtwarzały czy relacjonowały. Wróblewskiemu zależało zaś przede wszystkim na zmianie charakteru i definicji obrazu, na pojmowaniu go jako przedstawienia wieloplastycznego. W jego założeniu obraz miał być opowieścią, miał stanowić podstawę narracji, miał być osadzony w różnych źródłach humanistycznych. Analiza rozproszonych archiwaliów Wróblewskiego wskazuje, że realizacja wspomnianych przed chwilą założeń stała się możliwa pod koniec lat czterdziestych, kiedy to Wróblewski zaczął tworzyć i zarazem upowszechniać obrazy metaforyczne, uwikłane w poetycką triadę: czasu, miejsca i podmiotu. W swoim 
niespełna trzydziestoletnim życiu (1927-1957) stworzył kilka cykli tematycznych, w tym między innymi: Niebo nad górami, Rozstrzelania czy Zatopione miasta, które powstawały od końca lat czterdziestych XX wieku, w czasie szczególnym dla historii, ale także intensywnym okresie życia samego artysty.

W samej twórczości autora Nieba nad górami oraz w badaniach krytycznoliterackich poświęconych jego dziełom można napotkać odniesienia do mitu, mitologii czy mitologizacji. Autorzy poszczególnych prac łączą te pojęcia, świadomi ich podobieństw i różnic ze sztuką figuracji i abstrakcji, doszukując się w niej powiązań z dawnymi przedstawieniami, minionymi epokami. Inni zaś, jak Jan Michalski, zauważają w twórczości autora Ukrzesłowień związki z mitami literackimi, szczególnie zaś z wątkami romantycznymi, poprzez które artysta miałby ujawnić, tak istotne dla niego, rozdarcie podmiotu.

Mówiąc więc o mitologiach Wróblewskiego, rozumianych tu przede wszystkim za Wiesławem Juszczakiem (Juszczak 52-96) jako zapis i rekonstrukcja myślenia o sztuce, odkrywanie form nieobecności artysty w dyskursie literackim i wreszcie jako problem akcydentalności jego sztuki na tle twórczości modernistycznej, warto zapytać o relację mitu orfickiego i poezji oraz o problem naśladownictwa $\mathrm{w}$ pracach autora Treści uczuciowej rewolucji.

\section{Mit orficki. Problemy aktualizacji}

[...] zawrócił śladem tej postaci, co już z powrotem szła tą samą drogą [...] niepewnie, cicho, bez niecierpliwości.

(Rilke 99-100)

A potem umrę po raz drugi. Jak się umiera po raz drugi?

Mam nadzieję, że nie jest to takie bolesne i uciążliwe jak za pierwszym razem (Herbert 101)

Orfeusz, mityczny król tracki pozbawiony możliwości oglądania swojej żony Eurydyki zapisał się w historii literatury, poetyce i kulturze jako postać, która się odwraca. Punkt ciężkości tej opowieści skupia się jednak nie tyle na podmiocie, który się odwrócił, ale na samej czynności, momencie spojrzenia za siebie, spojrzenia w przeszłość. W Orfeuszu mieszały się bowiem dwie siły: pożądania i wytrwania, obie oparte na zwodniczym zmyśle wzroku. Oczy, symbolizujące tęsknotę za miłością, okazały się silniejsze od zakazu patrzenia, to one powiodły Orfeusza do Eurydyki, skazując bohatera na wieczną rozłąkę i odrzucenie.

Obraz „odwrócenia się", a raczej nieustannego „odwracania się" jest przykładem kulturowej interferencji przejawiającej się na różnych płaszczyznach literackich i artystycznych. W poezji zarówno Czesław Miłosz, Wisława Szymborska, 
Zbigniew Herbert, jak i Rainer Maria Rilke wpisywali motyw „odwrócenia się" w strukturę mitologii greckiej. Zwrócenie się ku przeszłości otwierało dyskusję wokół problematyki „,spojrzenia wstecz”. Miłosz ukazywał, że powodem odwrócenia się ku Eurydyce było zwątpienie Orfeusza we własne posłannictwo, zadanie. Herbert z kolei przenosił ciężar odpowiedzialności za czyn Orfeusza na Eurydykę, która z obawy przed powtórną, ponowną śmiercią nie chciała wrócić na ziemię, złączyć się ponownie z Orfeuszem.

W poetyckich odczytaniach tego mitu zderzają się ze sobą sprzeczne interesy dwóch jednostek, po pierwsze konieczność powrotu Eurydyki, o który dopomina się Orfeusz. Przeszłość zdaje się konstytutywna dla jego tożsamości, bez jej udziału nie jest w stanie określić swojego „tu i teraz”, a sama teraźniejszość jako jednostka czasu orfickiego po opuszczeniu Eurydyki nie istnieje. Po drugie, sprzeczną wobec pierwszego interesu jest postawa samej Eurydyki - ewokująca potrzebę odrzucenia losu, porzucenia przeszłości. Eurydyka pozostaje poza realnym i wyobraźniowym zasięgiem Orfeusza. Los odbiera mu doznania bliskości ukochanej, odbiera zdolność widzenia, odczuwania, obecności. Zawodzą wszelkie zmysły poznania.

Mit orficki w pewnym stopniu, zwłaszcza z uwagi na jego transpozycje we współczesnej literaturze, pozostaje meta-mitem. Interesującym tropem może być potraktowanie go jako kategorii metodologicznej w tekście. Józef Niżnik w artykule Mit jako kategoria metodologiczna (Niżnik 163-174) wskazywał na trzy możliwe orientacje mitu: orientację filologiczną, która traktuje go jako historię dosłowną, opartą na mythosie (stowie), następnie orientację filozoficzno-antropologiczną, dążącą do określenia społecznej funkcji mitu. W tym przypadku istotne jest badanie kontekstów, w jakich współcześnie funkcjonuje mit. Trzecia orientacja, publicystyczna, traktuje zaś mit jako opowieść potoczną, fikcyjną.

Warto zastanowić się nad celowością wykorzystania mitu orfickiego w sztukach wizualnych Wróblewskiego w kontekście jego wymiaru społecznego, filozoficzno-antropologicznego. Artysta poprzez swoje prace (po)wojenne - Rozstrzelania, Ryby bez głów, Rewizja - manifestował bowiem bycie z umarłymi, co wielokrotnie podkreślał także w swoich notatkach, pisząc, iż chce być głosem umarłych.

Odczytywaniem sztuki Wróblewskiego w kontekście mitu orfickiego w ostatnich latach zajęli się Jan Michalski oraz Anna Markowska. Michalski w książce Chłopiec na żóttym tle stawia diagnozę, iż niemal cała sztuka Wróblewskiego, jaka powstała w latach 1948-1957, oparta jest na micie orfickim. Tłumaczy to w rozdziale zatytułowanym Czaszka Orfeusza, rozpatrując postać autora Nieba nad górami jako awatar króla Tracji (Michalski 2009: 7-8). Autor przeprowadza w tym celu, moim zdaniem dość trafną i przekonującą, analizę etymologiczną imienia Orfeusz, wywodząc je z indoeuropejskiego rdzenia orbh- ('oddzielony, rozerwany') i greckiego orphe i orphanos ('ciemny, bez ojca, osierocony'). Te konotacje bezpośrednio łączą się z biografią Wróblewskiego. W wieku nastoletnim został osierocony przez ojca, który na skutek rewizji mieszkania dostał ataku serca i zmarł. Wychowaniem syna 
oraz jego brata, Jerzego po śmierci męża zajęła się matka, Krystyna Wróblewska, wileńsko-krakowska graficzka, pierwsza nauczycielka rysunku Wróblewskiego. Jej postać miała znaczący wpływ na kreowanie mitycznej postaci autora Zachodu słoń$c a$, to ona po tragicznej śmierci syna zajęła się porządkowaniem jego prac, nadając tytuły jeszcze nieoznaczonym obrazom.

Tymczasem poza dosłownością, przenikaniem historii Orfeusza do biografii Wróblewskiego artysta zdaje się tworzyć dzieła oparte na samej strukturze mitu. Uwidacznia się to w wyobraźni mitycznej, którą artysta ujawnia w cyklu rybich przedstawień. Ciemnozielone ryby z Obrazu na temat okropności wojennych, nazywanego też Rybami bez głów, pocięte na kawałki, nierówne, niepełne i niepokojące nawiązują do historii Orfeusza przebywającego na morzu, będącego w podróży po umarłą już Eurydykę, słyszącego z oddali pieśni żałobne i nieustające lamenty. Ale też przywołują i samą śmierć Orfeusza, którego rozszarpane przez menady ciało zostało rozrzucone po polach. Kontrast wody i ziemi Wróblewski oddaje dosłownie, pozbawia ryby wody, ich naturalnego środowiska. Ta rybia śmierć dokonuje się każdorazowo podczas oglądania niniejszego przedstawienia. Artysta poprzez zastosowanie ciemnozielonej, niejako mokrej barwy, wywołuje wrażenie, że ryby tuż przed chwilą zostały wyjęte $\mathrm{z}$ wody. Malarz nie daje widzowi zapomnieć o przeszłości.

Rybie przedstawienia zdominowały twórczość Wróblewskiego. Oprócz obrazów ichtycznych artysta tworzył szkice ryb. W ich przezroczyste wnętrza wpisywał litery, słowa, znaki, jakby chciał zamknąć właśnie w nich artystyczne przesłanie. Jego dzieło nie miało być wyłącznie powtórzeniem czy przedłużeniem, translacją mitu orfickiego, ale miało posiadać cechy orfickie.

Cała twórczość Wróblewskiego zdaje się być oparta na "odwrociu”, na oksymoronicznym „spojrzeniu w tył”. Mam tu na myśli zarówno cykle obrazowe: Rozstrzelania, Niebo nad górami czy liczne abstrakcje. W każdym z nich artysta nobilituje przeszłość. Z perspektywy językowej i fizjologicznej (słowo i ciało) spojrzenie w tył jest niemożliwe, oznacza bowiem kierunek przeciwny do kierunku patrzenia. Człowiek nie jest w stanie zobaczyć tego, co znajduje się bezpośrednio za nim, zmieniając jedynie kąt patrzenia, ustawienie ciała. Przeszłość jest niewidoczna. Aby ją ucieleśnić, nazwać, nadać jej kształt i zaakceptować, potrzebny jest świadek (z) przeszłości albo lustro.

Na marginesie rozważań o widzeniu w sztuce artystycznej autora warto dodać, iż Wróblewski był miłośnikiem fotografii lustrzanej. Uwielbiał fotografować samego siebie, siebie z żoną w lustrach. Zazwyczaj były to niewielkie lustra, pozbawione obramowania, co powodowało wrażenie otwartej przestrzeni. Artysta niemal na każdym zdjęciu pozostaje skupiony, wzrok zawsze kieruje na spust migawki, ma przymrużone oko. Wróblewski w bardzo niewielu przypadkach patrzy na nich na wprost, w teraźniejszość.

Powracając do problemu retardacji w sztuce Wróblewskiego, warto wskazać na obecność metafor i metonimii w jego dziełach oraz na ich znaczenie dla pozostałej 
twórczości artysty, jak metafory oka, drugiego (i trzeciego) oka, pamięci, pamiętnikarza, anamnezji. Ten środek artystycznego wyrazu wiązał się u Wróblewskiego z odwróconym podobieństwem. Artysta bardzo często tworzył całe cykle obrazów, w których powtarzał jeden motyw (ryby, niebieskie postaci, figury geometryczne, krzesła, marynarki), jakby poszukiwał alternatywnych określeń, odwracał się od powszechnych znaczeń. Metonimia natomiast związana była z całą warstwą słowną w dziełach Wróblewskiego, ustanawiała relacje między tym, co wizualne, a tym, co opowiedziane, między przedstawieniem a tytułem obrazu.

Istotna w całym tym kontekście pozostaje więc poetyka powtórzonego widzenia Wróblewskiego. Zwracała na nią uwagę między innymi Markowska, autorka Orfickich transkrypcji granicy. Późnych gwaszy Andrzeja Wróblewskiego. W książce Dwa przełomy. Sztuka polska po 1955 i 1989 roku (Markowska 2012) badaczka komentuje mit orficki w sztukach Wróblewskiego, charakteryzując go zdecydowanie szerzej, w odniesieniu do problemów filozoficznych. Markowska w micie orfickim widzi przede wszystkim transkrypcje postmemorialne. Zauważa, że artysta odwraca się ku przeszłości wielokrotnie, odwracanie czyni procesem swojej artystycznej pracy. Ma ono też silny wymiar morficzny. Notorycznie pojawiające się w twórczości autora Rozstrzelań czaszki: konturowane, kolorowane, malowane zmieniają optykę sztuki Wróblewskiego, w przeciwieństwie do twórcy one patrzą na wprost, bezpośrednio. Sam autor zdaje się dopuszczać jedynie konfrontację z przeszłością.

Mit orficki pozostaje ważnym i niezbędnym narzędziem do omówienia i interpretowania dzieł Wróblewskiego. Odczytywanie sztuki artysty przez pryzmat mitu orfickiego pozwala na wydobycie z dzieł artystycznego niuansu, umożliwia też stworzenie praktyki interpretacyjnej opartej na badaniu komparatystycznym i tym samym na rozpatrywaniu jego w sztuki w kontekście dosłownego myślenia mitologicznego.

Tym, co jeszcze łączy biografię Wróblewskiego z mitem orfickim, jest świadectwo powiązania estetyki z młodością życia i jego tragizmem. Jak pamiętamy z mitologii Jana Parandowskiego, Orfeusz był młody i bardzo piękny, choć spotkało go nieszczęście utraty Eurydyki. Wróblewski zginął w Tatrach w wieku niespełna 30 lat w nie do końca znanych okolicznościach, przez co jego śmierć została poniekąd mistycznie naznaczona. Jego życie, przesiąknięte dramatyzmem II wojny światowej, utratą ojca, wychowywaniem się w niepełnej rodzinie, pozostawiło trwały ślad w jego twórczości.

Widoczne jest to $\mathrm{w}$ wielu przedstawieniach $\mathrm{z}$ lat czterdziestych i pięćdziesiątych, w których autor starał się zachować pamięć uczestnika i świadka historii. Dlatego wiele obrazów i szkiców tworzył z perspektywy świadka: tłumu, jednostki, miasta, poczekalni. Autor jako obserwator życia pozostaje „maksymalnym detalistą". Poetyka jego obrazu jako takiego opiera się na wyolbrzymieniu szczegółu, fragmentu. Autor z całego spektrum widzialności, tego, co obejmuje wzrok, wybiera zazwyczaj jeden przedmiot, rzecz, postać, na której koncentruje swoją uwagę: 
krzesło, płaszcz, garnitur, buty, zabawki, postać matki, gestapowca, ofiary, naznaczając je odpowiednią barwą i tworząc następnie wariacje na temat analizowanego przedmiotu. To kolejny przejaw alternatywnej opowieści, jaką Wróblewski uprawia w swojej sztuce, alternatywy jednak koniecznej.

Zastanawiając się nad kolejnym znaczeniem mitu w twórczości Wróblewskiego, trzeba rozważyć przede wszystkim relację między nim (mitem) a biografią. Przypomnieć należy pierwsze sposoby definiowania biografii jako przedstawienia życia danego autora, a także koncepcję, zgodnie z którą twórczość pisarza współwynikała z jego minionych doświadczeń. W przypadku Wróblewskiego istotne wydają się jednak te próby biograficznego badania, które zakładają i umożliwiają „inność” czytania. Lata sześćdziesiąte przyniosły zwrot $\mathrm{w}$ badaniach nad biografizmem, wyłamującym się z myślenia strukturalnego. Coraz bardziej istotna pozostawała kwestia autokreacji w tworzeniu opowieści aż po zanegowanie obecności autora w procesie twórczym (śmierć autora). W przypadku malarza Matki z zabitym dzieckiem mamy do czynienia wyłącznie z gestami autobiograficznymi, próbując odtworzyć jego życiorys na podstawie pozostawionych przez niego fragmentów notatek i zachowanych materiałów. Do tego dochodzi również komplikacja biograficzna spowodowana działaniami matki po śmierci syna, utrudniającymi jednak stopień rozpoznania działań samego artysty.

Badanie biografii, jak wskazują literaturoznawcy, kulturoznawcy, socjologowie, łączy się niemal zawsze z analizą kategorii pamięci (pamięci własnej, zbiorowej), z kreacją i autokreacją, z białymi plamami w historii osobistej, a także z wszelkim kontekstem towarzyszącym pracom artystycznym. Wszystkie z wymienionych powyżej problemów mają swoje odzwierciedlenie w życiorysie Wróblewskiego. Artysta w małych kalendarzykach zapisywał ważne spotkania, informacje o wydarzeniach życia społeczno-kulturowego, nakreślał konteksty polityczno-historyczne swoich dzieł czy też zaświadczał o postępach prac nad danym cyklem obrazowym. Dyskusyjna wydaje się więc już sama działalność malarza: na ile była to kreacja własnego wizerunku artystycznego, która mogłaby posłużyć do tworzenia legendy, a na ile rzeczywista potrzeba zdawania rachunku przed samym sobą z postępów i metod pracy? Tajemnicza śmierć artysty w górach w zdecydowany sposób wpłynęła na dalsze kreowanie postaci artysty.

W tym kontekście interesujący pozostaje projekt „innego” biografizmu Sławomira Rzepczyńskiego. Autor proponuje wprowadzenie do badań nad życiem i twórczością pojęcia tekstualności biografii:

Na czym polegałaby natomiast tekstualność biografii? Przede wszystkim na tym, że do biografii (czyjegoś przeżywanego życia), jeśli nie traktujemy jej jako tego, co aktualnie przeżywane, dostęp mamy tylko poprzez jej tekstualne zmediatyzowanie. Dotyczy to nie tylko aktu poznania czyjejś biografii, która może być prezentowana $\mathrm{w}$ formie opowieści, a więc przekształcona $\mathrm{w}$ tekst, ale także biografii własnej, której reminiscencje 
przybierają formę (auto)przekazu tekstualnego. Jeśli zatem mamy do czynienia z biografią, która jawić się może jako tekst, i z literaturą, która z natury swej jest tekstualna, to elementy wspólne obu tych przestrzeni można widzieć jako kategorie względnie jednorodne, które proponowałbym określić jako interteksty. Intertekstem będzie to, co wspólne dla biografii i dzieła literackiego, co rozpoznawalne w obu tych przestrzeniach (Rzepczyński 174).

Zaproponowany przez badacza termin można odnieść do artystycznego wizerunku Wróblewskiego. Proces ten dokonuje się na podstawie zarówno tekstów samego artysty: Wróblewskiego-publicysty, jak i tekstów o artyście, zwłaszcza zaś poezji alternatywnej. $W$ pozostawionych po sobie notatkach, pismach i apelach Wróblewski wyrażał sprzeciw wobec ówczesnych poglądów społecznych, historycznych i politycznych, które miały znaczący wpływ na kształtowanie życia akademickiego. Wtedy już ukazywał się jako inteligent-buntownik, domagający się stworzenia nowej jakości sztuki i nowej edukacji artystycznej, czego przykładem jest poniższy fragment apelu:

Akademia powinna dziś spełniać, oprócz swej tradycyjnej roli „wtajemniczenia”, obowiązki narzucone jej przez potrzeby chwili: powinna potęgować kontakt studenta ze społeczeństwem, uczyć go włączania życia społeczeństwa w zakresie zainteresowań artystycznych. Akademia powinna być instytucją ułatwiającą studentowi kontakt z wszelką sztuką, najstarszą i najnowszą. Powinna popierać eksperymenty, stwarzać jak najbogatsze środowisko koleżeńskie, uczyć wcześnie odpowiedzialnych wystąpień publicznych (Wróblewski 294).

Wróblewski w swojej pracy artystycznej dążył do ujawnienia granicy między rzeczywistością a jej zakłamaniem, do wyjaśnienia i wyartykułowania poprzez sztukę różnicy między prawdą a fałszem. Wypełnienie tego założenia mogło się odbyć jedynie poprzez radykalny gest Wróblewskiego, a mianowicie poprzez dokonanie samodzielnego wyboru między polityczną, społeczną a kulturową rolą praktyki artystycznej, o czym pisał Branislav Dimitrijević (Dimitrijević 484).

Z przywołanych autokomentarzy, szkiców krytycznych, tekstów publicystycznych Wróblewski jawi się przede wszystkim jako postać stanowcza i zdeklarowana, jednym słowem silna. Jeśliby próbować oceniać jego postać przez pryzmat pokolenia, Wróblewski mógłby pozostać liderem grupy. W rzeczywistości jednak, mimo radykalności swoich poglądów, autor zmagał się z problemem własnej tożsamości.

Istotny w jego twórczości pozostaje zapowiadany rok 1948, w którym Wróblewski namalował obraz zatytułowany początkowo Treść uczuciowa rewolucji. To przedstawienie z serii astronomicznej, kosmogonicznej typowej dla malarstwa geometrycznego. Artysta przygotował go na I Wystawę Sztuki Nowoczesnej, zorganizowaną w Krakowie na przełomie 1948 i 1949 roku. Pole obrazowe wypełniają 
różnokolorowe koła, niestykające się ze sobą, dominują w tym przedstawieniu następujące barwy: dosadna czerwień, wyrazisty niebieski, ostra biel, poświaty koloru zielonego, brązowego, beżowego. Artysta traktuje każde koliste przedstawienie osobno, część z nich opatruje wyrazistym konturem, inne pozostawia bez wyraźnej granicy. Tym obrazem Wróblewski manifestował swój stosunek do rewolucji, upatrując w niej pozytywnej zmiany. Forma i formuła tego dzieła przypominają działanie kalejdoskopu, a właściwie zatrzymanie jego ruchu na granicy zmiany kolorów, na granicy przekształceń.

Historia tego przedstawienia, rozpatrywanego w kontekście późniejszej sztuki artysty, pozwala spojrzeć na nie zdecydowanie wielokierunkowo. Istotna wydaje się analiza poetyki recto/verso, którą uprawia artysta. Wyraża się ona w malowaniu po dwóch stronach tego samego płótna. Na rewersie, drugiej stronie obrazu artysta umieścił w 1949 roku Dworzec na Ziemiach Odzyskanych przedstawiający ludzi oczekujących na peronie na podróż, zmianę, decyzję, tworzony już w zupełnie innej poetyce, ideologii i wyobraźni. To obraz przełamujący myślenie o rewolucji jako pozytywnej zmianie. To moment w malarstwie Wróblewskiego, w którym zaczyna dominować barwa ciemnozielona, moment tworzenia w nurcie socrealizmu dla większej masy odbiorców. Jednocześnie to również czas, w którym Wróblewski niezwykle silną uwagę skupia na przedstawieniu wszelkich form „oczekiwania na coś". To obraz przygotowany w podobnym czasie co Poczekalnia, Ukrzesłowienie, ukazujące dramatyzm ludzi pozostawionych działaniu władzy, uzależnionych i pozbawionych samodzielnych decyzji.

Treść uczuciowa rewolucji pozostaje jednak znacząca w historii malarstwa Wróblewskiego nie tylko pod względem formalnym, ale przede wszystkim symbolicznym. Ten okres w twórczości autora Dwóch mężatek wpisuje się w kreowany przez artystę Mit Nowego Kosmosu, o czym wspominał Jan Michalski (Andrzej Wróblewski, źródło elektroniczne). Jak pisałam wcześniej, Wróblewski po wojnie dążył do stworzenia nowego świata, także artystycznego, opierającego się na nowym znaczeniu, nadawaniu innego sensu, stworzeniu nowego języka modernizmu.

W tym kontekście bardziej czytelna wydaje się więc dwoistość jako główna cecha charakterystyczna jego twórczości. Można więc przypuszczać, że artysta tworzy swoje dzieła w oparciu o archetyp i nową sygnaturę. Archetyp to pamięć dawnych mitów: archetyp Matki (obrazy rodzinne, obrazy kobiet karmiących, studia kobiecego ciała), archetyp Cieni (sprzeciw wobec społecznej rzeczywistości, obrazy rodzajowe, sceny z życia codziennego), archetyp Starego Człowieka (studium człowieka uwikłanego w los i historię). Poprzez sygnaturę, wpisywanie siebie w obraz, ujawnia się indywidualność w obrazach Wróblewskiego, co widać głównie w autoportretach, a także na fotografiach samego siebie w lustrze. Sygnatura wiąże obrazy Wróblewskiego z personą, osobowością, mitem artysty.

W przypadku Wróblewskiego niemożliwe zdaje się jednak pełne odtworzenie biografii. Wciąż wiele fragmentów jego życiorysu pozostaje nieznanych - sła- 
bo rozpoznany okres wileński, nieokreślone relacje z matką w wieku dojrzałym, tajemnicza śmierć artysty $\mathrm{w}$ górach - i być może nigdy nie zostaną rozpoznane. Problem z niewspółmiernością kategorii badawczych sygnalizuje być może, iż $\mathrm{w}$ odczytywaniu sztuki i życia artysty potrzeba obecnie posłużenia się formami hybrydycznymi.

Przykładem takiej formy jest anglosaskie pojęcie biomitografii wprowadzone do literatury polskiej za sprawą Jungowskiej psychoanalizy. Współcześnie służy ono opisywaniu związków życia i literatury w twórczości romantyzmu. Biomitografia wiąże się pamięcią, wyobraźnią historyczną, skupia się głównie na konkretyzacji. $\mathrm{W}$ biomityzacji ujęty zostaje również problem potraktowania dzieła jako zastępczego materiału biograficznego. O związku biografii z mitem pisał Ira Bruce Nadel w następujący sposób:

Biografia przetwarza jednostkowe starania w przeżycia mityczne. Reprezentatywny aspekt życia, obrazujący doświadczenia jednostki, uniwersalizuje się. Jest to przejście od metonimii do metafory, przeniesienie indywidualnych życiowych zmagań na płaszczyznę uogólnień. I właśnie dzięki uniwersalizacji opowieści, wykorzystującej w tym celu archetypy i konwencje, biografia przechodzi ze sfery historii w sferę mitu (Nadel 178, cyt. za: Chomiuk 68).

Biomitografia jako narzędzie badawcze może być pomocna przy omawianiu różnych faz życiorysu Wróblewskiego - począwszy od narodzin twórcy, relacji z matką artystką, czasu akademickiego, okresu socrealizmu, samotności twórczej aż po śmierć w Tatrach, a zwłaszcza pośmiertną recepcję w literaturze polskiej.

\section{Wróblewski - Różewicz}

Według notatek żony artysty Teresy Reutt, jak podaje Michalski, w 1955 roku Wróblewski maluje cykl gwaszy Gimnastyczki (styczeń), Mały chłopak, Plaża, Uwaga, nadchodzi (marzec), w maju cykl rysunków do poezji Federica Garcíi Lorci, a w październiku (miesiącu urodzin poety) cykl rysunków do poezji Różewicza. W 1956 roku w szkicowniku jugostowiańskim zapisuje scenariusz i tworzy rysunki do filmu o Różewiczu. Poniżej za Michalskim przytaczam notatki artysty:

I. wojna - terror

- partyzantka

- straty (śmierć bliskiego)

II. kompleks powojenny:

naprzemian - pustka wewnętrzna 
- ukojenie u kobiety

w przerwach - drobnomieszczaństwo

III. epilog z niezwiązanych ze sobą efektów drobno-lirycznych

(tylko III cz. - kolorowa?)

postacie

autor (narrator-recytator)

młody uszminkowany trochę na mima

dziewczyna-żona, specjalnie macierzyńsko-kobieca, b. młoda

matka

sposób interpretacji wiersza:

a) dromnomieszcz.: (prawie) bez tekstu, nagromadzenie ujęć

b) wiersze odautorskie deklamowane $\mathrm{z}$ dosłowną ilustracją filmową

c) inne - metoda mieszana, osadzenie wiersza w formalnej i literackiej większej całości

(Michalski 1993: 184-185)

Obok notatek znajduje się szkic jakby głośnika, megafonu, ale zarazem jakby widzialnego oka ze strzałkami skierowanymi w przeciwne strony wraz $\mathrm{z}$ dopiskiem „wstęp, tło do czołówki, główny przerywnik”. Lata pięćdziesiąte były dla Wróblewskiego czasem intensywnej lektury, obok Różewicza interesowała go twórczość Louisa Aragona, Karola Marksa. Wróblewski pisał o pojawiającej się wówczas potrzebie „odwoływania się do wszelkich skojarzeń o charakterze pojęciowym, literackim, jakie budzi dany motyw” (Michalski 1993: 101). Inspirowała go przede wszystkim sztuka „poetycko-uczuciowa”, aspirująca do rangi arcydzieła. Zespolenie z twórczością Różewicza po pierwsze mogło gwarantować artyście podobny rodzaj przeżycia estetycznego, po drugie sprzyjało rozszerzeniu języka realizmu. Owo zespolenie malarstwa i poezji dokonywało się na kilku płaszczyznach: pokoleniowej (doświadczenie wojny, traumy, utraty), humanistycznej (pojmowanie literatury/sztuki jako przestrzeni otwartej, dialogicznej) i imaginatywnej (skłonność do nadrealizmu).

Różewicz nawoływał wówczas do nowego języka narracji. Gesty liryczne autora Opowiadania dydaktycznego połączone z gestami malarskimi twórcy Rozstrzelań wskazują na wiele semantycznych podobieństw. Problem uwikłania języka w sztukę, ale też i uwikłania go w tradycję kultury podjął w swych pracach poeta. Paralela Różewicz - Wróblewski zdaje się więc kontynuacją przekroczenia myśli awangardowej, co poeta czyni poprzez ujawnienie problemów afektu oraz koniecznej rzeczywistości (postulatu realizmu), ponadto Różewicz opowiada się za deformacyjną koncepcją rzeczywistości Wróblewskiego (deformacja cielesna, karykaturalność, nadrealizm) i postulatem tak zwanej innej sztuki socrealistycznej. 
Robert Cieślak w Widzeniu Różewicza podkreśla istotny wpływ jego poezji na kształtowanie imaginatywnej pamięci zbiorowej. Mnie z kolei w sposób szczególny interesuje problem estetyki, który przy okazji rozważań nad kategorią piękna porusza badacz, przywołując fragmenty różewiczowskiej prozy:

Od wielu miesięcy pracuję nad innym wierszem. Spotkanie na Piazza S. Marco. Pierwotnie chciałem ograniczyć się tylko do opisu zlatujących tutaj gołębi, turystów i umarłych. Wśród zlatujących gołębi widziałem też anioły. Nie tylko te pospolite dwuskrzydłe, ale również wieloskrzydłe serafiny. [...] Zmarli mieli się pojawić wśród turystów, mieli być ubrani tak, jak ich zapamiętałem, mieli podpływać na gondolach do kamiennego nadbrzeża. Albo sami mieli kołysać się na falach jak łodzie. Mam więc tu umówione spotkanie ze Staffem, Gilem, Tuwimem, Gałczyńskim, z Andrzejem Wróblewskim i Janiną Mortkowiczową. Jedna osoba przybyła na to spotkanie z odległego czasu dzieciństwa. Jedna i nieproszona. Tamte osoby prosiłem, wabiłem, sypałem im groch z papierowej torebki (cyt. za: Cieślak 26).

Wróblewski figuruje w powyższym fragmencie jako postać wywoływana i oczekiwana. Różewiczowi chodzi jednak o coś więcej aniżeli o proste, bezprecedensowe zwrócenie uwagi na samą postać artysty. Poeta wskazuje przede wszystkim na podobieństwo estetyki tekstu i obrazu. Widać to zwłaszcza w realizacji mitu utraconego dzieciństwa, mitu orfickiego (Różewicz - utrata matki, Wróblewski - utrata ojca) czy też mitu odejścia (odejścia zmarłych, bliskich). Interesujące w perspektywie kreacji poetyckiej pozostają przede wszystkim formy uobecnienia Wróblewskiego w twórczości autora Czerwonej rękawiczki.

Szczególnym przykładem jest Opowiadanie dydaktyczne, w którym najbardziej uwiarygadnia się relacja między Różewiczowską metaforą nowego czasu i zaczynu a postsocjalistycznym malowaniem Wróblewskiego. W tym poemacie dedykowanym Mieczysławowi Porębskiemu Różewicz wspomina o decydującym dla życia, sztuki, artyzmu momencie uważności. Zderza ze sobą piękno i brzydotę, wyobrażenie i rzeczywistość, podkreślając przy tym, że to właśnie artysta jako pośrednik opowieści mitycznej pozostaje tym, który zauważa te rozbieżności, dychotomie, stopnie estetyk:

\author{
bliski mojemu sercu \\ śmietnik wielkomiejski \\ poeta śmietników jest bliżej prawdy \\ niż poeta chmur \\ śmietniki są pełne życia \\ niespodzianek
}

(Różewicz 1996: 35) 
W drugiej części poematu, uznawanej za oniryczną, pojawia się postać Wróblewskiego, tajemniczo przywoływana w tekście. Na ten poetycki gest gry z Wróblewskim zwracał uwagę Marcin Jaworski w artykule Różewicz i Bruegel. Raz jeszcze o miejscu poety po końcu poezji oraz o "Opowiadaniu dydaktycznym", zastanawiając się nad znaczeniem tego precedensu w twórczości Różewicza:

Właśnie ów status artysty wydaje się w Opowiadaniu dydaktycznym szczególnie interesujący, utwór zyskuje $\mathrm{w}$ tomiku zawsze fragment interesujące sąsiedztwo, umieszczony jest między wierszami: W świetle lamp filujących oraz W gościnie u Henryka Tomaszewskiego w Muzeum Zabawek. Z jednej strony utwór poświęcony Schulzowi, z drugiej - ślad po prywatnej relacji z wybitnym współczesnym artystą. To wzmacnia osobistą i autotematyczną wymowę poematu, w którym występują Andrzej W. w drugiej wersji zamieniony na Andrzeja Wróblewskiego, oraz Franciszek, potem jako Franciszek Gil, i który w każdej wersji opatrzony jest dedykacją: Mieczysławowi Porębskiemu (Jaworski 244).

Badacz powołuje się dalej w tekście swojej rozprawy na Mieczysława Porębskiego:

Różnica to istotna. Andrzej W. jest postacią literacką, o której ",jest mowa" w poemacie, tyle też tylko o nim wiadomo: że chciał budować zamki na lodzie [...]. Andrzej Wróblewski, malarz, przyjaźniliśmy się z nim, zginął w Tatrach 23 marca 1957 r. [...] (Porębski 19).

Różewiczowskie uobecnianie artysty, erudycyjne, poetyckie, jest daleko poza sztuką. Różewicz nie patrzy na Wróblewskiego wyłącznie jako na artystę nowego modernizmu, spogląda na niego przede wszystkim jako na świadka pamięci, poetę i malarza historii, która nigdy się nie kończy. W tym ciągłym zapatrzeniu, w kontekstach, innych interpretacjach, w wierszach, obrazach wciąż rozszerza się mitologia artystyczna Wróblewskiego właśnie za sprawą poezji.

Na przełomie marca i kwietnia 1948 roku powstał Klub Artystów, którego prezesem został Tadeusz Kantor. Zrzeszał on malarzy, literatów, architektów, w tym między innymi Tadeusza Różewicza, Kornela Filipowicza, Jerzego Nowosielskiego, Andrzeja Wróblewskiego czy Marię Jaremiankę. W tym samym roku w Krakowie Klub zorganizował I Wystawę Sztuki Nowoczesnej, podczas której wystawiono prace artystów tworzących po zakończeniu wojny. Celem tej prezentacji miała być konfrontacja języków sztuki awangardowej, zaznajomienie odbiorców z nową estetyką. Podczas tego spotkania Różewicz odczytywał swoje wiersze, starając się potwierdzić mit utylitarności nowej sztuki. Coraz bardziej jednak artyści dostrzegali defragmentyzację rzeczywistości.

Obaj artyści, Różewicz i Wróblewski, powracali w swojej pracy do mitu kosmogonicznego. Zdawali sobie jednocześnie sprawę, iż niemożliwa jest jego pełna kreacja, doskonałe odtwórstwo. Stąd w procesie re-kreacji posługiwali się katego- 
rią fragmentu rozumianego na kilku płaszczyznach: jako koncepcja nieukończenia dzieła, sposób mówienia o doświadczeniach (post)traumatycznych i (po)wojennych, przejaw mentalnej amputacji pamięci, element wyparcia oraz pułapka interpretacyjna.

Widać to wyraźnie w przedstawieniach geometryczno-kosmicznych Wróblewskiego, za pomocą których artysta dążył do ponownego scalenia rozdartej powojennej rzeczywistości, ale i manifestował wolność sztuki. Nagromadzenie kól, okręgów w obrazach z lat czterdziestych i pięćdziesiątych symbolizowało powtórzenie czasu, uwikłanie narracji w symbol. To samo zjawisko można zaobserwować w poetyce Różewicza, gdzie świat oglądany jest z dwóch perspektyw: centralnej i peryferyjnej. Nasze widzenie jest ograniczone i ma dwa pola: centralne - tam, gdzie kierujemy nasz wzrok, i peryferyjne, gdzie zachodzi już deformacja rzeczywistości. Badanie przestrzeni peryferyjnej wymaga odwrócenia perspektywy widzenia $\mathrm{z}$ tematu popularnego na temat wyparty, gdzie wzrok początkowo nie sięga lub sięgać nie chce:

Słyszę chrobotanie

To ta staruszka drapie

pazurkami po ścianie

i kaszle jak zwierzątko

Więc idę do niej

siadam przy okrągłym stole

a ona wywołuje duchy

ze spodeczka popija herbatę

drobnymi jak ptak łykami

Na eteżerce panowie

z bródkami

„jenseits von Gut und Bose”

ostatnia ćwierć XIX wieku

Potrząsa suchą główką

i opowiada o Wenecji

Florencji o słońcu Italii

Ja jestem baronówna $\mathrm{z}$ domu

To jest koniec świata

teraz nowe gwiazdy wymyślili i słońca

- mówi -

i oczy jej zachodzą łzami.

(Różewicz 2005: 250) 
W przywołanym powyżej utworze Różewicz traktuje słońce jako symbol rewolucji artystycznej zaproponowanej przez Wróblewskiego w Treści uczuciowej rewolucji, która w swojej wymowie okazuje się dramatyczna. Posługiwanie się wielością środków, budowanie nowych języków nie prowadzi do osiągnięcia doskonałego świata. Bohaterka wiersza Różewicza na myśl o nowej wyobraźni, o "wymyślaniu” świata popada w rozpacz. Wprowadzenie "nowego" do literatury i sztuki nie zatrzymało postępującej degradacji świata. Środkiem pośrednim miał stać się fragment powstały w czasie deformacji.

Różewicz wielokrotnie podejmuje próbę stworzenia nowej całości, czego przykładem może być recycling rozumiany jako maksymalizacja ponownego wykorzystania materiałów - będzie to jednak całość przekształcona, zdeformowana dwukrotnie. Deformacja pierwsza to wyłączenie „wszystkiego” z tradycyjnego ujęcia, zaś deformacja druga to umieszczenie dawnej całości w ponowoczesnym widzeniu jedności. Interpretacja „nowego" może odbyć się jedynie drogą wykluczenia. Zdaje się, że ten stan w stopniu najwyższym osiągnął również Wróblewski, poddając swoją sztukę działaniu (de)mitologizacyjnemu.

Posługiwanie się mitem $\mathrm{w}$ historii twórczej autora Nieba nad górami pozwala na definiowanie sztuki Wróblewskiego w dwóch ujęciach: pojmowanie jej jako skończony akt twórczy, w którym odbiorca zostaje poddany narracji, jak również jako dążenie do zakończenia procesu, w którym widz zostaje zobowiązany do rekonstrukcji i ukontekstowienia dzieła.

Dlaczego więc myślenie mitologiczne pozostaje koherentne z twórczością Wróblewskiego? Po pierwsze dlatego, że sztuka bywa fenomenologią zjawień i zdarzeń, archeologią kultury, po drugie też dlatego, że wywołuje z nieświadomego, jest siostrą poezji, domagającą się trwania na granicy wyjaśnionego i utraconego. Mit sprzyja również scalaniu wspólnoty, zgodnie z tym, co zostało powiedziane na I Wystawie Sztuki Nowoczesnej:

Dla nowoczesnego artysty sztuka jest metodą wyobrażeniowego przyswajania sobie świata. Dlatego horyzonty nowoczesnej sztuki, nauki i techniki są wspólne. Pomieszczone w sali wejściowej fotogramy ukazują świat, który jest w tym samym stopniu światem artysty, co światem naukowca - badacza albo praktyka - technika (Wystawa sztuki nowoczesnej zorganizowana przez Klub Artystów w Krakowie, 24).

\section{Zakończenie}

Ta krótka interpretacja sztuki Wróblewskiego wskazuje na potrzebę coraz bardziej kontekstowego myślenia o sztuce autora Rozstrzelań. Pokazuje też konieczność badania jego obrazów w oparciu o biografię artystyczną i języki modernizmu, które 
od lat pięćdziesiątych funkcjonowały w opowieściach o malarzu. Sztuka Wróblewskiego domaga się więc omawiania jej w kontekście problemu powtórzenia, zwracając uwagę widza-czy telnika na kwestie zarówno indywidualnego, jak i zbiorowego uwikłania w (r)ewolucję.

Propozycja czytania twórczości Wróblewskiego dodatkowo w oparciu o kategorie mitu, mitologii, mitologizacji pozwala wyraźnie dostrzec czynniki literackie w twórczości artystycznej autora. Tym samym też ukazuje potrzebę rozszerzenia interpretacji obrazu o pokrewne estetyki okresu lat czterdziestych i pięćdziesiątych z uwzględnieniem przeobrażeń poetyckich, estetycznych i pokoleniowych. Świadome i odważne dostrzeganie sygnałów komparatystycznych może bowiem przyczynić się do szerszego upowszechnienia wciąż jeszcze mało znanych tekstów i prac Wróblewskiego

\section{BIBLIOGRAFIA}

Całek, Anita. Biografia naukowa. Od koncepcji do narracji: interdyscyplinarność, teorie, metody badawcze. Kraków: Wydawnictwo Uniwersytetu Jagiellońskiego, 2013.

Chomiuk, Aleksandra. „Biomitografie Henryka Sienkiewicza”. Annales Universitatis Paedagogicae Cracoviensis. Studia Poetica IV (2016). S. 68-81.

Czermińska, Małgorzata. Autobiografia i powieść, czyli pisarz i jego pisarze. Gdańsk: Wydawnictwo Morskie, 1987.

Czermińska Małgorzata. Autobiograficzny trójkąt: świadectwo, wyzwanie, wyznanie. Kraków: Towarzystwo Autorów i Wydawców Prac Naukowych Universitas, 2000.

Cieślak, Robert. Widzenie Róźewicza. Warszawa: Wydawnictwa Uniwersytetu Warszawskiego, 2013.

Dimitrijević, Branislav. „Folklor, nowoczesność i śmierć. Wizyta Wróblewskiego w Jugosławii”. Unikanie stanów pośrednich. Andrzej Wróblewski (1927-1957). Red. M. Ziółkowska, W. Grzybała. Warszawa: Fundacja Andrzeja Wróblewskiego, Instytut Adama Mickiewicza, Hatje Cantz Verlag, 2014. S. $482-525$.

Eliade, Mircae. Aspekty mitu. Warszawa: Wydawnictwo KR, 1998.

Herbert, Zbigniew. „H.E.O.”, Polonistyka 2 (1997). S. 101.

Jaworski, Marcin. „Różewicz i Bruegel. Raz jeszcze o miejscu poety po końcu poezji oraz o «Opowiadaniu dydaktycznym»". Literatura i sztuka. Tom 2. Tadeusz Różewicz i obrazy. Red. A. Stankowska, M. Śniedziewska, M. Telicki. Poznań: Poznańskie Towarzystwo Przyjaciół Nauk, 2015. S. 239-249.

Juszczak, Wiesław. Poeta i mit. Wołowiec: Wydawnictwo Czarne, 2014.

Michalski, Jan. Chłopiec na żóttym tle. Teksty o Andrzeju Wróblewskim. Kraków: Galeria Zderzak, 2009.

Michalski, Jan. Andrzej Wróblewski nieznany. Kraków: Galeria Zderzak, 1993. Web. 20.01.2019. <http:// zderzak.pl/oferta-wroblewski.html>.

Nadel, Ira Bruce. Biography. Fiction, Fact and Form. London: MacMillan, 1984.

Niżnik, Józef. „Mit jako kategoria metodologiczna”. Saryusz-Wolska Magdalena, Traba Robert. Kultura i Społeczeństwo 3 (1978). S. 163-174. 


\section{DARIA NOWICKA, ARTYSTA I MIT. WOKÓŁ TREŚCI UCZUCIOWEJ REWOLUCJI...}

Napiórkowski, Marcin. „Mit”. Modi memorandi. Leksykon kultury pamięci. Warszawa: Wydawnictwo Naukowe SCHOLAR, 2014. S. 237-240.

Porębski, Mieczysław. „Wstęp”. Różewicz Tadeusz. Zwierciadto. Poematy wybrane, wybór M. Porębski. Kraków: Wydawnictwo Literackie, 1998. S. 17-28.

Rilke, Rainer Maria. „Orfeusz. Eurydyka. Hermes”. Polonistyka 2 (1997). S. 99-100.

Rottenberg Anda, red. Perspektywa wieku dojrzewania. Szapocznikow - Wróblewski - Wajda. Katowice: Muzeum Śląskie, 2018.

Różewicz, Tadeusz. Zawsze fragment. Wrocław: Wydawnictwo Dolnośląskie 1996.

Różewicz, Tadeusz. zawsze fragment. recycling. Wrocław: Wydawnictwo Dolnośląskie, 1999.

Różewicz, Tadeusz. Zwierciadło. Poematy wybrane. Wyb. M. Porębski. Kraków: Wydawnictwo Literackie, 1998.

Różewicz, Tadeusz. Utwory zebrane VII: Poezja 1. Wrocław: Wydawnictwo Dolnośląskie, 2005.

Rzepczyński, Sławomir. „Projekt «innego» biografizmu”. Stupskie Prace Filologiczne. Seria Filologia Polska 5 (2007). S. 171-176.

Saryusz-Wolska Magdalena, Traba Robert. Modi memorandi. Leksykon kultury pamięci. Warszawa: Wydawnictwo Naukowe SCHOLAR, 2014.

Skrzyniarz Ryszard, Krzewska Elżbieta, Kuryluk Edmund, red. Biografia w literaturze i sztuce. Lublin: Wydawnictwo Episteme, 2014.

Stankowska Agata, Śniedziewska Magdalena, Telicki Marcin, red. Literatura i sztuka. Tom 2. Tadeusz Różewicz i obrazy. Poznań: Poznańskie Towarzystwo Przyjaciół Nauk, 2015.

Ubertowska, Aleksandra. Holokaust. Auto(tanato)grafie. Warszawa: Instytut Badań Literackich PAN, 2014.

Ziółkowska Magdalena, Grzybała Wojciech, red. Unikanie stanów pośrednich. Andrzej Wróblewski (19271957). Warszawa: Fundacja Andrzeja Wróblewskiego, Instytut Adama Mickiewicza, Hatje Cantz Verlag, 2014.

Wojciechowski Aleksander, oprac. Andrzej Wróblewski. Warszawa: Arkady, 1979.

Wróblewski, Andrzej. „Jeszcze w sprawie szkół plastycznych”. Wieś 47 (1948).

Wróblewski, Andrzej. „”Oto idzie”, Andrzej Wróblewski nieznany. Red. J. Michalski et al., Kraków: Galeria Zderzak, 1993. S. 199.

Wystawa sztuki nowoczesnej zorganizowana przez Klub Artystów w Krakowie, katalog wystawy. Warszawa, 1948.

Zimand, Roman. „Uwagi do przyszłej biografii Brzozowskiego”. Wokót myśli Stanistawa Brzozowskiego. Praca zbiorowa. Red. A. Walicki, R. Zimand. Kraków: Wydawnictwo Literackie, 1974. S. 378.

Venclova, Tomas. Wilno. Przewodnik biograficzny. Przeł. Beata Piasecka. Warszawa: Państwowy Instytut Wydawniczy, 2013. 